\title{
Article
}

\section{Transformation of Distribution Logistics Management in the Digitalization of the Economy}

\author{
Alexander Parfenov ${ }^{1}$, Lubov Shamina ${ }^{2}$, Jiahui Niu ${ }^{3}$ and Vladimir Yadykin ${ }^{4, *}$ \\ 1 Department of Logistics and Supply Chain Management, Petersburg State University of Economics, \\ Saint Petersburg 191123, Russia; parfenof@mail.ru \\ 2 Department of P1 Organization Management, Baltic State Technical University, \\ Saint Petersburg 190005, Russia; shamina_lk@voenmeh.ru \\ 3 Shenzhen Research Institute, Renmin University of China, Shenzhen 100872, China; niujiahui@mail.ru \\ 4 Laboratory "Advanced Production Technologies" of the National Technological Initiative Center, \\ Peter the Great St. Petersburg Polytechnic University, Saint Petersburg 195251, Russia \\ * Correspondence: v.yadikin@mail.ru
}

check for

updates

Citation: Parfenov, A.; Shamina, L.; Niu, J.; Yadykin, V. Transformation of Distribution Logistics Management in the Digitalization of the Economy. $J$. Open Innov. Technol. Mark. Complex. 2021, 7, 58. https://doi.org/10.3390/ joitmc7010058

Received: 24 December 2020

Accepted: 2 February 2021

Published: 6 February 2021

Publisher's Note: MDPI stays neutral with regard to jurisdictional claims in published maps and institutional affiliations.

Copyright: (c) 2021 by the authors. Licensee MDPI, Basel, Switzerland. This article is an open access article distributed under the terms and conditions of the Creative Commons Attribution (CC BY) license (https:// creativecommons.org/licenses/by/ $4.0 /)$.

\begin{abstract}
A problem predicted by experts with the onset of the COVID-19 pandemic is that many markets, in particular, the restaurant market, the tourism market, and the entertainment market, will face long-term stagnation in the near future due to outflow of financial resources. On the other hand, even though the standards of social interactions have changed, the basic needs of modern society for nourishing and varied food, entertainment and experiences cannot disappear as a result of a pandemic. The goal of our study consisted of gaining insights into the new hybrid practices of logistics and customer services that business needs to master in the new environment, combining offline and online activities. We have found that success in the market is achieved by organizations that regularly generate new entrepreneurial, scientific and technical ideas and consolidate their own and attracted resources to create, develop and launch new products, services and technologies on the market. Employing analytical methods, we have characterized the drivers of the transformation of distribution logistics management in the context of the digitalization of the economy, concluding that this process primarily affects the management of distribution channels. The features of transformation in the management of international distribution channels are studied. The requirements for logistics management in this functional area of management are defined.
\end{abstract}

Keywords: logistics; omnichannel; distribution; sustainable development; digitalization; e-wholesale

\section{Introduction}

Numerous studies have considered diverse aspects of digital transformation [1-4]. In particular, Vilken et al. [5] discussed the deployment and operation of innovative supply chains within a regional economy, and Bril et al. examined the engineering applications of the Internet of Things [6,7]. Our study characterizes the driving forces that determine the transformation of distribution logistics management in the context of the digitalization of the economy, in view of the onset of the pandemic causing a number of negative chain reactions. They had a negative impact on the state of the world economy and international trade, which face long-term-stagnation in the near future. However, many countries have already passed the peak of the epidemic and its associated restrictions. It can be expected that the process of removing the forced isolation of their domestic markets will not be delayed and the scale of international trade will gradually recover as the demand for food, entertainment and experiences persists in society. It is also clear that the characteristics of domestic markets will not remain the same [8]. In view of these considerations, we set the goal of exploring the practices evolving in different spheres of production, logistics and customer services. Comprehensive analysis was carried out to identify the key drivers of the digital transformation of distribution logistics, in particular, the management of 
distribution channels. Considering the data accumulated for the global e-commerce market, we managed to uncover the practices that organizations need to adopt to achieve success in these new conditions.

To gain insights into the problem, the authors have carried out an analytical review of publications dedicated to the problems and prospects of the digitalization of logistics and supply chain management, finding that the number of works produced on this subject has been steadily increasing. The complexity of distribution channels for logistics transformation will be also taken into account. The researchers attempt to consider the argument that the digitalization of the global economy reduces the risks of negative impacts of various factors on international trade (including the difficulties of distribution logistics management in the conditions of the COVID-19 pandemic).

\section{Literature Review}

The analysis was carried out by ontological methods to identify the fundamental features of logistics in the digitalization of the economy for understanding the structure, patterns of development and interaction of digital trading platforms, associated with the logistics process. To consider this extensive topic, we propose to apply a general methodological approach to solving the problem of systematizing the conceptual framework (Figure 1).

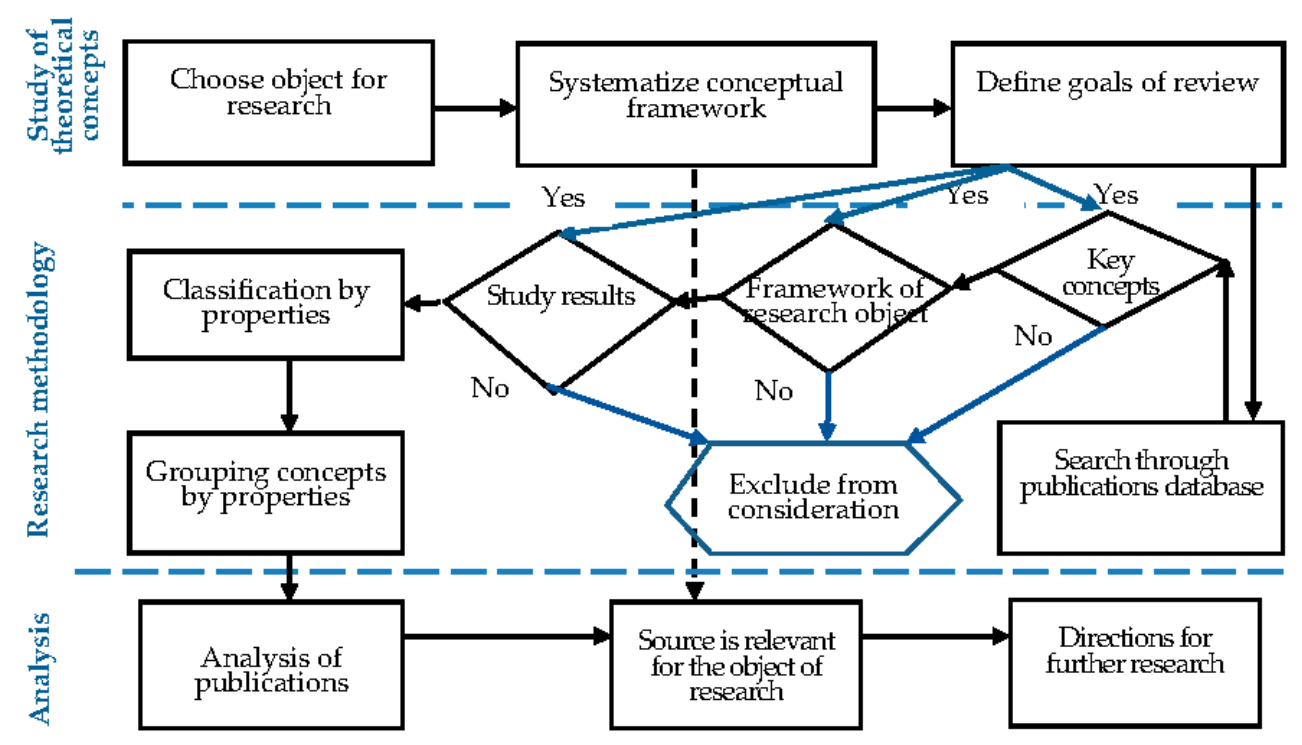

Figure 1. The methodology of the research.

The proposed methodology takes into account that from a technical standpoint, digital objects are fairly well understood, although there are many definitions for the concept. The researchers suggest a hypothesis that the competition between distribution channels is transitioning towards a competition between digital trading platforms. The analysis of the trends of e-commerce will allow us to define the main drivers of the transformation of distribution logistics management and to suggest the classification of international logistics distribution channels in the digitalization of the economy.

It is beyond doubt that the pandemic has created objective prerequisites for changing the structure of the trade industry in a number of countries. Some of its participants have lost their positions to some extent. This situation, according to the theory developed by Michael Porter [9], creates real opportunities for the development of domestic markets by foreign suppliers. Secondly, the recession, which affected all countries, led to an increase in the rational component in consumer behavior [10]. The system-forming factor of this trend was their adaptation, first of all, to the lack of financial resources. It is obvious that the demand structure has already changed under its influence. However, we cannot ignore the 
fact that the reaction of consumers was also reflected in the postponement of the purchase of goods. Domestic markets in many countries have therefore acquired the potential for deferred demand [11]. Thirdly, the forced isolation of businesses and households during the pandemic has unexpectedly given a new light to the prospects for both e-commerce and the digitalization of this industry. All this, on the one hand, serves as an incentive for enterprises engaged in foreign economic activity to enter foreign markets, i.e., to expand the scope of international trade. However, on the other hand, it actualizes the task of developing a new approach to managing the logistics of goods distribution abroad, whose priorities in the context of the total trend of the digitalization of the world economy need to be revised [12].

The main attention is paid to assessment of the direction of the impact of the digitalization of the economy on changes in logistics processes at enterprises of various industry directions, and analysis of the practice of using information technologies in logistics management [13-15]. Most of these works show at least two general points of view. Firstly, the digitalization of logistics is actually reduced to the construction of specialized Information Technology (IT) platforms that allow for major changes in the logistics activities of enterprises, i.e., to switch to innovative work regulations. Secondly, digital progress has the most obvious impact on only one type of operational logistics activity: transportation [16]. Note that a number of papers provide predictive estimates for the development of digital logistics $[17,18]$.

However, the focus on the functional areas of logistics is fragmentary at best. Although the definition of e-SCM (supply chain management) has been generally established [19], the place of this concept in procurement management is not understood well enough. For example, the possibility of using agent modeling to solve problems of managing distribution channels of development is not taken into account in [6]. A notable study [20] postulates that the digitalization of the economy causes the transformation of interactions within supply chains. In our opinion, the study of this trend is more relevant today than ever. Our review of publications shows that the impact of the digitalization of the economy on the management of distribution logistics is mainly related to omnichannel sales. The relationship between digital logistics and omnichannel trade, however, is rarely considered and usually in the context of retail trade [21,22]. Except some rare cases, the omnichannel category has a pronounced marketing context in this industry. For example, in [21] it is characterized from the standpoint of increasing the volume of additional and crossselling retail sales by integrating and synchronizing contacts with consumers based on IT technologies. The exception is [23], describing the specifics of the influence of this form of sales on the direction of reorganizing distribution channels. In addition, the logistical problems of forming an omnichannel model of wholesale trade are justified in this study. Thus, our analysis of the work on this issue indicates an increasing interest towards the digitalization of logistics and SCM. At the same time, the analysis shows that the changes in some areas covered by logistics management, in particular, in the management of distribution logistics, require further examination.

\section{The Analysis of Trends of E-Commerce}

\subsection{Global E-Commerce Market: Current State and Development Trends}

A trend we can observe is that e-commerce has been growing by $23 \%$ year-on-year, global e-commerce sales are expected to exceed USD 27 trillion in 2020, and these figures are projected for the retail sector alone (Figure 2).

By the end of 2019, the global e-commerce market reached USD 3.5 billion, accounting for $14 \%$ of the total share of retail sales in the world (https:/ /www.statista.com/globalconsumer-survey?from $=\% 252$ Fglobal-consumer-survey $\% 252$ Fsurveys). 


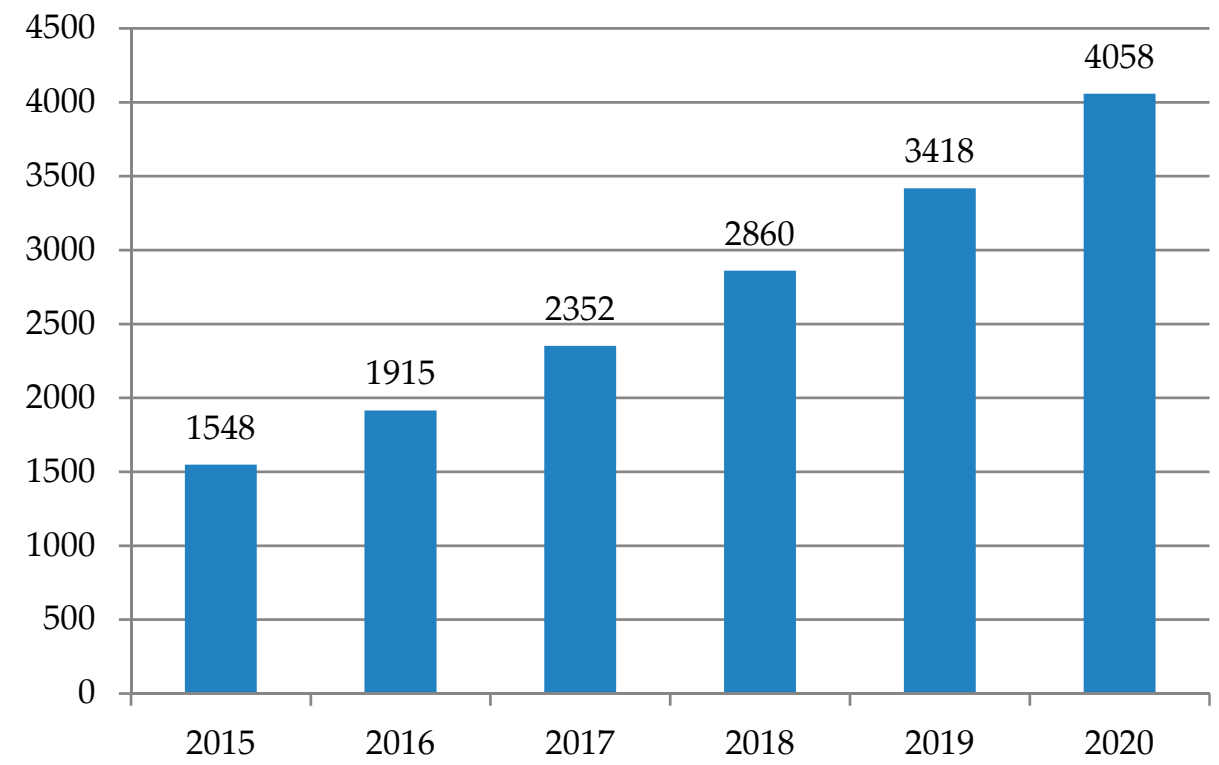

Figure 2. Volumes of retail e-commerce for 2015-2019 and forecast for 2020.

The total sales in e-commerce are shown in Figure 3 (billion USD).

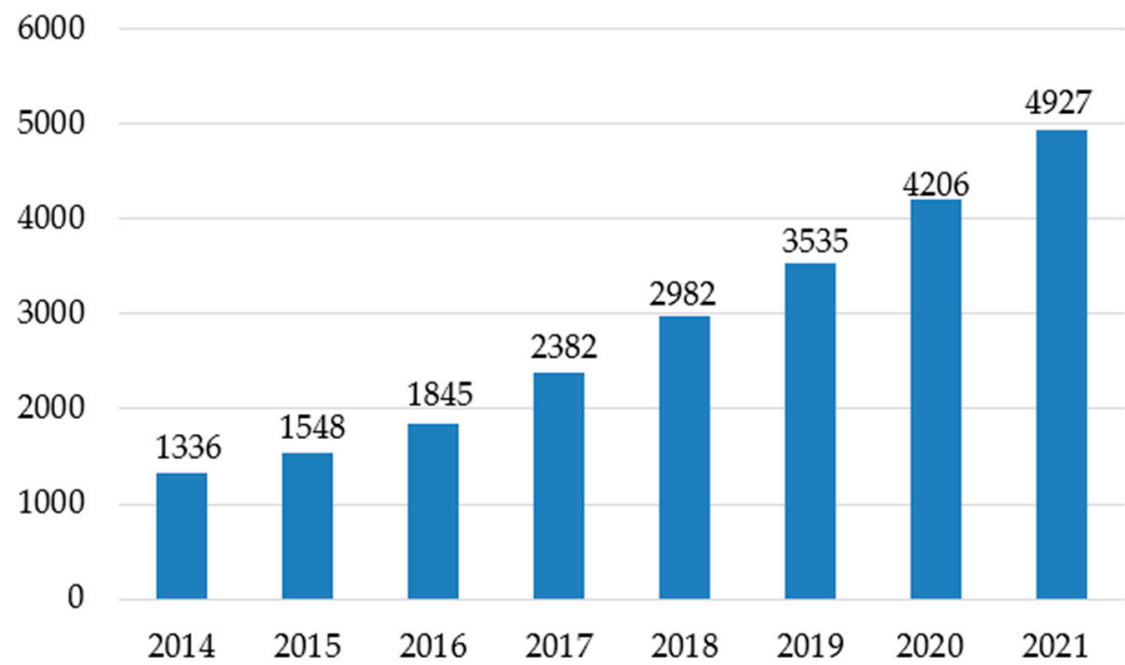

Figure 3. Global e-commerce sales for 2014-2019 and forecast for 2020-2021.

"These data predict that global e-commerce sales will reach USD 4.2 billion by the end of 2020 , accounting for $16 \%$ of the total retail sales" (https:/ / www.statista.com/outlook/ 243/100/ecommerce/worldwide). "These figures are projected to keep growing into the 2020s" (https:/ / www.emarketer.com/content/more-digital-trends-2021-digital-fitnesstelemedicine-digital-food-delivery-emerge-new-triple-threat).

Even though China's consumer economy has been experiencing a slowdown, the Asia-Pacific region will still be the leader in global e-commerce growth in 2020 . The region is expected to grow by $25.0 \%$ to USD 2.271 trillion, accounting for $64.3 \%$ of the global e-commerce spending. Latin America and the Middle East/Africa will grow at a year-onyear rate of $21.3 \%$, which is slightly above the global average, with North America (14.5\% growth) and Western Europe (10.2\%) lagging behind (see Figure 4). 


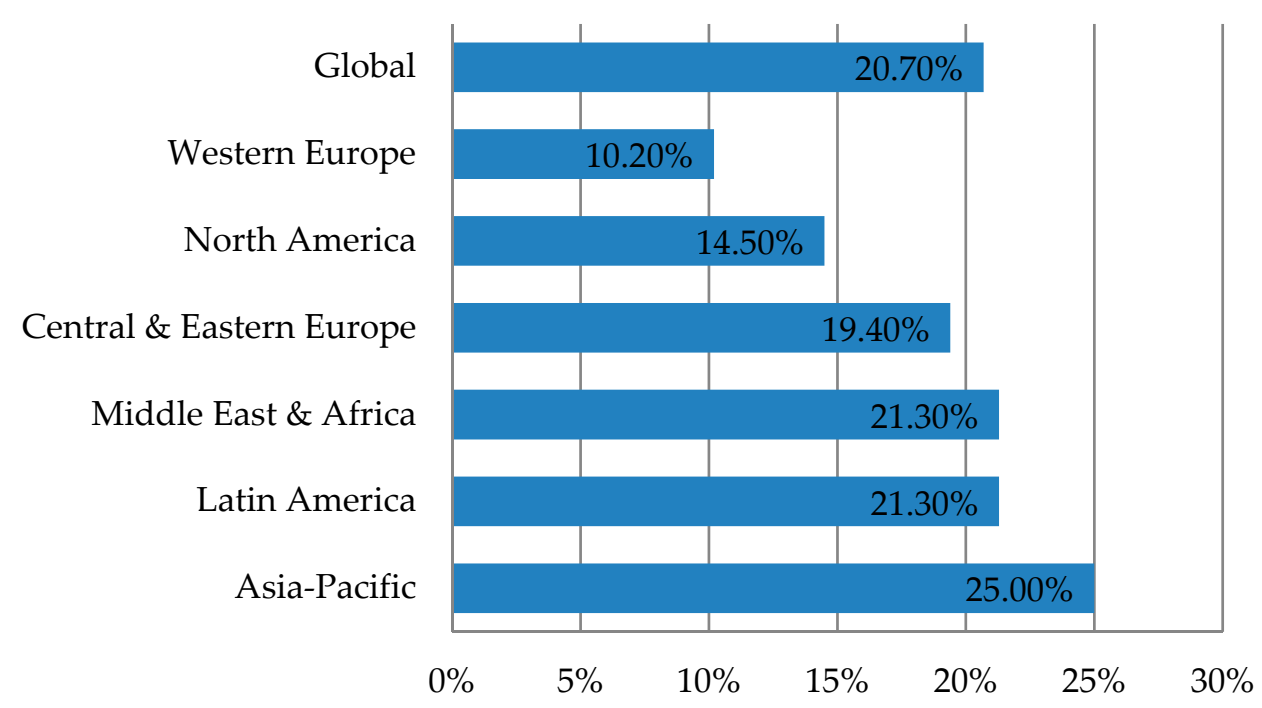

Figure 4. Forecast of global growth in retail e-commerce in 2020 by region.

Six of the 10 fastest-growing e-commerce countries in 2019 are from Asia Pacific, led by India and the Philippines with over $30 \%$ growth, along with the aggregate growth from China, Malaysia, Indonesia and South Korea. Latin America boasts the fastest growing e-commerce market, with Mexico at 35.0\% and Argentina ranking 8th. More mature ecommerce regions such as North America (Canada, 21.1\% growth) and Europe (Russia, $18.7 \%$ growth) ranked in the Top 10 (Figure 5).

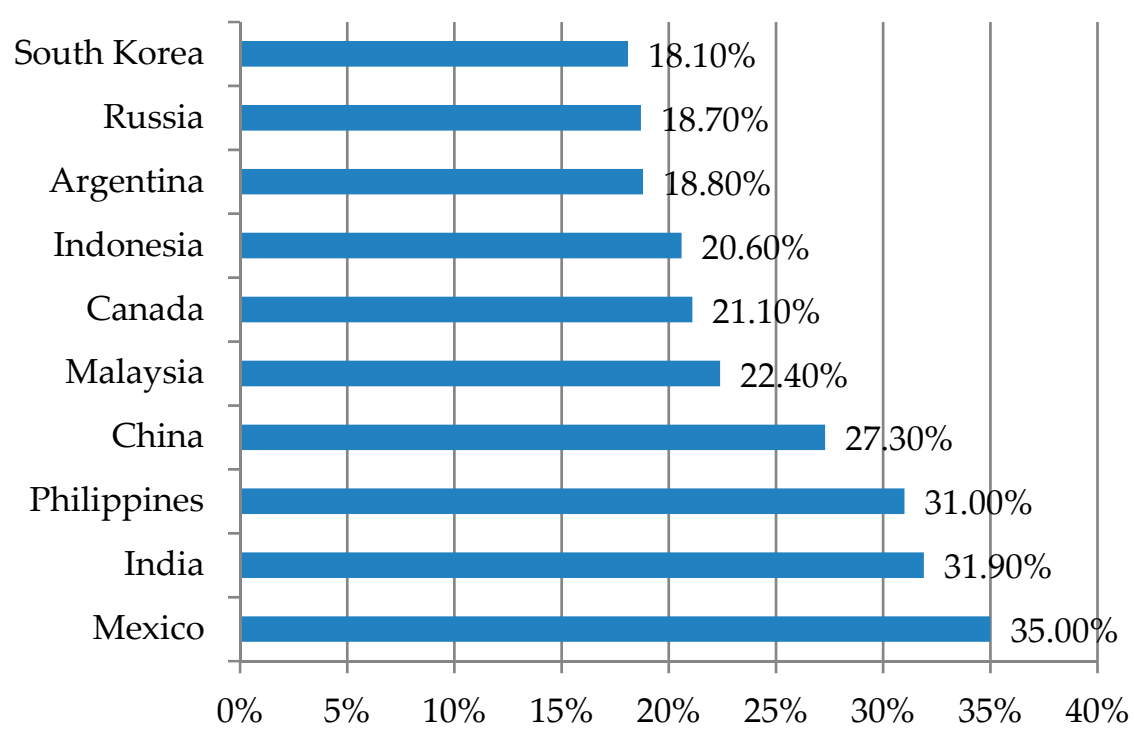

Figure 5. Top 10 countries by e-commerce growth in 2019 .

\subsection{The World's Best E-Commerce Markets}

China became the world's largest e-commerce market in 2019, with e-commerce sales of USD 1.935 trillion, more than three times that of the second-largest US market with USD 586.92 billion. This seems incredible, but China only recently surpassed the US in e-commerce sales in 2013 for the first time. It has rapidly expanded margins since then. China itself represents $54.7 \%$ of the global e-commerce market, nearly double the share of the next five countries combined. The global e-commerce market follows the trends in China (Table 1). 
Table 1. Top 10 countries by e-commerce volumes in 2018-2019, billion USD.

\begin{tabular}{cccc}
\hline Countries & $\mathbf{2 0 1 8}$ & $\mathbf{2 0 1 9}$ & Growth, \% \\
\hline China & 1520.1 & 1934.78 & $27.3 \%$ \\
USA & 514.84 & 586.92 & $14.0 \%$ \\
UK & 127.98 & 141.93 & $10.9 \%$ \\
Japan & 110.96 & 115.4 & $4.0 \%$ \\
South Korea & 87.6 & 103.48 & $18.1 \%$ \\
Germany & 75.93 & 81.85 & $7.8 \%$ \\
France & 62.27 & 69.43 & $11.5 \%$ \\
Canada & 41.12 & 49.80 & $21.1 \%$ \\
India & 34.91 & 46.05 & $31.9 \%$ \\
Russia & 22.68 & 26.92 & $18.7 \%$ \\
\hline
\end{tabular}

Western Europe accounts for three of the top six e-commerce markets, led by the UK (USD 141.93 billion), Germany (USD 81.85 billion), and France (USD 69.43 billion); as these markets are more mature, each has shown growth compared to the same period last year.

This contrasts with Canada's relatively advanced Internet market, which continues to grow at a strong rate. The world's 8 th e-commerce market grew by $21.1 \%$ to USD 49.80 billion in 2019. Even though Canada's economy is generally mature, its e-commerce has traditionally lagged behind due to inefficient logistics. Canada's population is geographically dispersed from its western to eastern borders, making the costs of e-commerce distribution centers and delivery opportunities more prohibitive. Recent improvements now help reallocate spending online at an accelerated rate.

The fastest growing e-commerce market in the top 10 is India, with sales expected to grow by $31.9 \%$ this year to USD 46.05 billion. Even though India is one of the largest economies in the world, its e-commerce market is relatively new, largely due to its lowincome population and still immature infrastructure supporting payments and delivery.

"The trends shown in Figure 6 are expected to prevail in cross-border e-commerce in 2020-2021" (https:/ / www.bigcommerce.com/articles/b2b-ecommerce/b2b-ecommercetrends/).

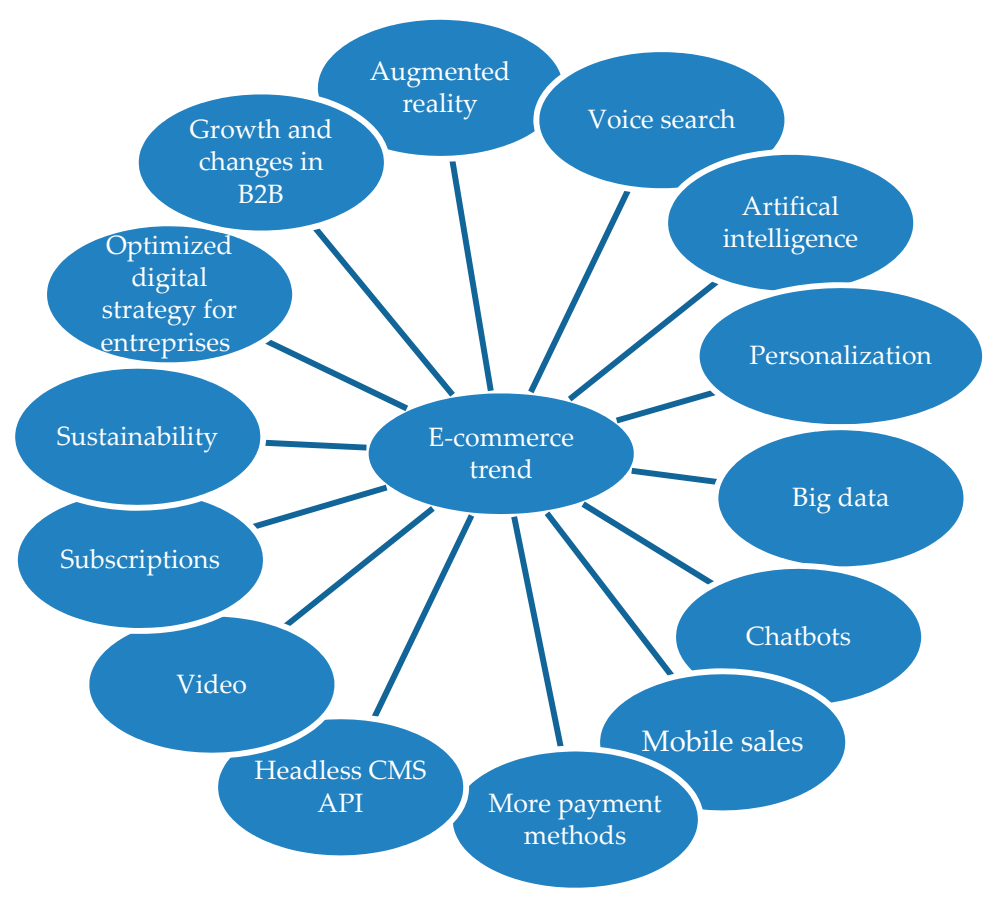

Figure 6. Trends in cross-border e-commerce. CMS-Content Management System; API-Application Programming Interface; B2B-business-to-business. 


\subsection{Cross-Border Operating Models: China's Experience}

The cross-border B2C model (business to consumer) is represented by several Chinese companies, including LightInTheBox, Globalegrow, and Focal Price (Table 2). While these companies have the same profit model, they differ in logistics and marketing models.

Table 2. Overview of Chinese companies with cross-border business to consumer (B2C) operating model.

\begin{tabular}{ccllll}
\hline $\begin{array}{c}\text { E-Commerce } \\
\text { Company }\end{array}$ & Founded & \multicolumn{1}{c}{ Sector } & Profit Model & Logistics Model & Marketing Approach \\
\hline Lightinthebox & 2007 & $\begin{array}{l}\text { computers-consumer } \\
\text { communications } \\
(3 C) \text { products }\end{array}$ & $\begin{array}{l}\text { Difference between } \\
\text { purchase and sale prices }\end{array}$ & Third-party logistics & $\begin{array}{l}\text { scanning electron microscope } \\
\text { (SEM), media advertising, affiliate } \\
\text { advertising, advertising mail }\end{array}$ \\
\hline Globalegrow & 2014 & $\begin{array}{l}\text { Clothing and } \\
\text { electronics }\end{array}$ & $\begin{array}{l}\text { Difference between } \\
\text { purchase and sale prices }\end{array}$ & Overseas warehouse & $\begin{array}{l}\text { SEM, advertising, email } \\
\text { marketing, social networks }\end{array}$ \\
\hline Focal Price & 2008 & 3C products & $\begin{array}{l}\text { Difference between } \\
\text { purchase and sale prices }\end{array}$ & Direct mail & $\begin{array}{l}\text { SEM, Salomon Nordic } \\
\text { System (SNS) }\end{array}$ \\
\hline
\end{tabular}

The cross-border B2B (business to business) model allows manufacturing and trading companies to publish information and sell their goods through digital platforms such as Alibaba, Global Sources, China Manufacturing, and Dunhuang (Table 3).

Table 3. Overview of Chinese companies with cross-border B2B operating model.

\begin{tabular}{cccccc}
\hline $\begin{array}{c}\text { E-Commerce } \\
\text { Company }\end{array}$ & Founded & Sector & Profit Model & Logistics Model & Marketing Approach \\
\hline Dhgate & 2004 & Department store & System commission & Warehouse delivery, EUB & $\begin{array}{l}\text { Search Engine Optimization } \\
\text { (SEO), SEM, advertising mail, } \\
\text { SNS, British Broadcasting } \\
\text { Corporation (BBS) }\end{array}$ \\
\hline $\begin{array}{c}\text { Made-in- } \\
\text { China.com }\end{array}$ & 1998 & Department store & Member fees & SEM \\
\hline Global sources & 1970 & Promotion & Service charge & Marketing through social \\
TradeManager & 1999 & Department store & Service charge & Third-party logistics & SEO, SEM \\
\hline $\begin{array}{c}\text { Eastern } \\
\text { Industrial }\end{array}$ & 2015 & Industrial hardware & Service charge & Overseas warehouse & $\begin{array}{l}\text { Online and offline } \\
\text { showrooms }\end{array}$ \\
\hline Tradetang & 2007 & Department store & Service charge & $\begin{array}{c}\text { Uninterruptible Power } \\
\text { Supply (UPS), Dalsey } \\
\text { Hillblom Lynn (DHL), } \\
\text { Express Mail Service (EMS), } \\
\text { Thomas Nationwide } \\
\text { Transport (TNT), FEDEX }\end{array}$ & SEO, SEM \\
\hline
\end{tabular}

Table 4 shows the best-known Chinese companies using the B2B2C model (business to business to consumer) in cross-border e-commerce.

In general, our findings confirm that there is a trend towards growth in China's wholesale e-trade, and we believe that this sector of this digital economy holds good prospects despite the negative effects of the pandemic. 
Table 4. China's best-known companies using the business to business to consumer (B2B2C) model in cross-border e-commerce.

\begin{tabular}{cccccc}
\hline $\begin{array}{c}\text { E-Commerce } \\
\text { Company }\end{array}$ & Founded & Sector & Profit Model & Logistics Model & Marketing Approach \\
\hline DealeXtreme & 2006 & Department store & Profit from sales & Post packet & $\begin{array}{c}\text { Marketing forum, } \\
\text { marketing through } \\
\text { social networks }\end{array}$ \\
\hline Dinodirect.com & 2009 & Department store & $\begin{array}{c}\text { Difference between } \\
\text { purchase and } \\
\text { sale prices }\end{array}$ & $\begin{array}{c}\text { Overseas } \\
\text { warehouse }\end{array}$ & $\begin{array}{c}\text { Cross-border Online to } \\
\text { offline (O2O), marketing } \\
\text { through social networks }\end{array}$ \\
\hline Beltal & 2015 & Department store & Commission & $\begin{array}{c}\text { International } \\
\text { express }\end{array}$ & Micro-financing \\
\hline Milanoo & 2008 & Fashion clothing & Profit from sales & UPS, DHL & SEM \\
\hline
\end{tabular}

\section{Results}

The most obvious driving force behind the transformation of distribution logistics management priorities in the context of the digitalization of the world economy is, of course, the widespread penetration of IT technologies in this functional area. However, it is not the only one.

There is a pronounced tendency towards the increasing influence of participants in distribution channels as they approach the end users. This influence is related to our sensitivity to changes in customer requests, among other things. Recall that generating this property for distribution channels belongs to the class of traditional marketing tasks [24]. There are numerous factors behind the importance of this problem, including: (1) the need to effectively ensure the transformation of the production range into the retail range and further down the distribution channel, respectively, a series of successive changes in the retail range (as deeper penetration of the market to the retail links of the product movement); (2) the complexity of focusing on the needs of end users in the conditions of using an aggressive demand management strategy by manufacturing enterprises (its elements are: (a) artificial reduction in the life cycle of production technologies and goods; (b) customization, i.e., giving individual characteristics to mass-produced goods; (c) a wide supply of goods on credit); (3) erasing interspecies product boundaries in retail trade (including as a result of the transition from product unit management to product category management); (4) market dominance of retail chains, etc. It should be noted that the loss by producers (classical owners of distribution channels) of the status of the most influential participants (in terms of understanding the needs of end users and tracking the dynamics of changes in their preferences), in fact, leads to the fact that the classical structures of distribution channels become unviable [25].

The expectation of global structural shifts in economic communication systems as a result of the transition from competition between distribution channels to economic competition between digital trading platforms is such a force [26,27]. It is worth noting that the advent of a new digital era of competition in commodity markets will directly affect, first of all, international distribution channels. Our analysis of actual data allows us to draw the following conclusions. Firstly, the subject content of the "distribution channel" category is interpreted in the same way in most of them, with the exception of some discrepancies $[28,29]$. Secondly, the typologies of these channels are either not represented in them, or do not fully correspond to modern economic realities. One of the reasons for this is due to insufficient attention to the theory of trade mediation in the context of the digitalization of the economy. With the purpose to provide an integral representation of the characteristics of logistics distribution channels in international trade, we propose their classification, which is shown in Figure 7. 


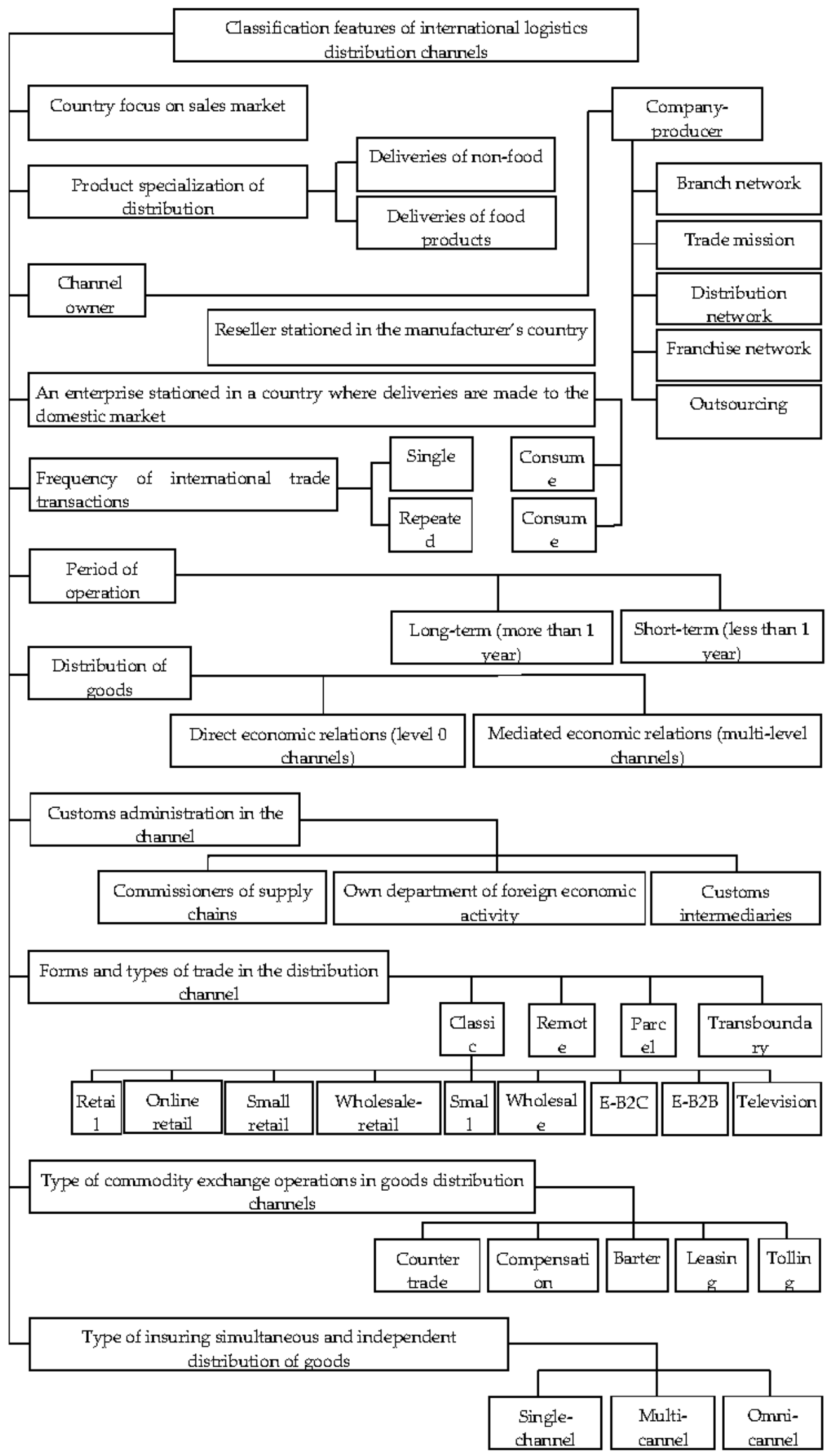

Figure 7. Classification of international logistics distribution channels. 


\section{Discussion}

The features of logistics distribution transformation in the digital economy, in our opinion, cannot be explained only by the fact that the owners of these channels do not always pay sufficient attention to their participants, i.e., trade intermediaries [30]. This statement also applies to the conclusion in [31], according to which these owners often see intermediaries as obstacles to trade with end users, since they can accept orders from them in electronic format.

We could discuss that one of the main problems of the transformation of distribution logistics management is the complexity of both balancing the owners of distribution channels for logistics and other interactions with resellers. The real reasons for actualizing this problem are deeper. Consistent balancing of interactions of the trade intermediaries, as we know, is the main strategy for ensuring sustainable development of the enterprise (channel owner). Moreover, in our opinion, it should be noted that the pandemic has created prerequisites for rethinking the classical approach to creating conditions for sustainable development of the distribution channel by achieving a balance of logistics interactions between its participants. Achieving this goal, particularly in long international supply chains, is not an easy task. In a similar vein, [32] discusses how the open innovation concept can be analyzed from an industrial dynamics perspective, focusing on the complex interplay between technology entrepreneurs and incumbents. Of course, the lack of proper attention to interactions with trade intermediaries is also explained by the difficulty of calculating the profitability of the distribution channel $[33,34]$. The main prerequisite for channel owners to enter into a logistical conflict with trade intermediaries in the Russian Federation has recently acquired a distinct institutional character. According to [35], the reason for that is that distribution contracts are not recognized in Russian practice, and, as a result, enterprises are discouraged from entering associations that could ensure their overall competitiveness. Conversely, such logistics cooperation is supported in the USA [36]. Another driver is the need to transfer logistics infrastructure facilities (logistics centers, etc.) in distribution channels to the "demand response" mode [37]. An important driver of the transformation of distribution logistics management priorities is the tendency to translate classical transaction operations into the digital dimension [38]. Additionally, it is advisable to pay special attention to ensuring business continuity in distribution channels [39].

The transformation of distribution channels regards the concept of open innovation dynamics. So, it should be borne in mind that it goes beyond the classic logistics boundaries. A concept model of open innovation built up in [40] is intended for exploring the existing open innovation channels, which can be useful to motivate engineering research increasing the development of open innovation and new open business models.

Discussing the data analysis, the authors agree that different conditions and modes of operation characterizing different countries should be taken into consideration. Undoubtedly, the increase in the volume of online sales can be smaller in a country where digital sales have already been in a very large volume for a longer time when compared with the increase in sales in a country where online sales have been recently emerging. The authors agree that the volume of online sales per capita could provide good insights for comparisons of dynamic trends in the economy of various countries. Future research could regard the analysis of concrete data, giving a good insight into the phenomenon of a large territory with very spread population.

\section{Conclusions}

Thus, the digitalization of the global economy reduces the risks of negative impacts of these factors on international trade. For example, electronic customs declaration helps to reduce the time of cargo delay at the state border. At the same time, the digitalization of the economy leads to drastic changes in all functional areas of global logistics. This is reflected, in particular, in the transformation of the management of international logistics channels due to their increased focus on omnichannel services. The nature of changes in this type of management could be determined by the need to abandon the practice of 
using product distribution channels abroad, which excludes horizontal interaction between them, in favor of forming a "seamless" multi-channel system that provides an omnichannel mode of logistics service to consumers. The driver of these changes is the growing trend of e-commerce development. We could discuss that all this changes the strategic and operational priorities of logistics for the distribution of goods in international markets.

The distribution of goods in international trade is based on the classical principles of logistics management. The complexity of managing this process is disproportionately higher than in the case of trading on the domestic market of a single country. This situation is traditionally conditioned by the following factors:

(1) The high length of international supply chains;

(2) Cultural and institutional differences in the regulation of processes in these multiple organizational structures;

(3) Differences in the quality of national logistics infrastructures, etc.

Multi-channel distribution, which is carried out by the majority of focus companies, considers that a significant number of participants inevitably creates objective difficulties in controlling the quality of relationships, including logistics, between them. This situation is compounded in practice by the fact that resellers, in particular, independent sales representatives, very often adhere to a policy of diversification of interactions with suppliers. One of its consequences is that these intermediaries hold back sales of products from individual suppliers, despite their high profitability. The probability of the owner of the distribution channel intercepting orders for the supply of goods from end users using the Internet is very high. However, the statement of this fact should not be regarded as a true circumstance that forms the image of an obstacle in the face of trade intermediaries in the mind of the channel owner. It should be recalled that, in particular, the distribution agreements clearly state the obligation of the focus company not to accept orders from consumers stationed in the territory that was assigned to the reseller (official distributor). The need for this is determined by at least three factors: (1) the loss of the need for supply planning based on long-term forecasts due to the digitalization of the economy (increasing information awareness); (2) the need to involve these facilities in the logistics service of e-commerce channels; (3) the increasing relevance of cross-delivery between different distribution channels.

It should be noted at once that the blockchain technology in logistics, as practice shows, does not always give an unambiguous result. In addition, it should be taken into account that the problem of ensuring digital security in distribution logistics is quite large. Regarding this, some various scenarios describing the possible effects of COVID-19 could be modelled. The automation of various industries seems to have intensified during the pandemic, with an emphasis on replacing people. This may certainly affect the buying power of the population in a long-term perspective, with a visible impact on the volume of e-commerce.

Author Contributions: All the authors have contributed substantially to the entire work reported. Conceptualization, A.P. and J.N.; methodology, L.S. and V.Y.; writing—drafting, V.Y.; writing—inputs, all authors; writing - reviewing and editing, all authors. All authors have read and agreed to the published version of the manuscript.

Funding: The study was supported by the Academic Excellence Project 5-100 proposed by Peter the Great St. Petersburg Polytechnic University.

Institutional Review Board Statement: Not applicable.

Informed Consent Statement: Not applicable.

Data Availability Statement: Data available in a publicly accessible repository.

Acknowledgments: The authors would like to thank the anonymous referees for their very useful suggestions.

Conflicts of Interest: The authors declare no conflict of interest. 


\section{References}

1. Schislyaeva, E.; Saychenko, O.; Barykin, S.; Kapustina, I. International Energy Strategies Projects of Magnetic Levitation Transport. In International Scientific Conference Energy Management of Municipal Facilities and Sustainable Energy Technologies EMMFT 2018; Springer: New York, NY, USA, 2019; pp. 313-320.

2. Ilin, I.; Kalinina, O.; Barykin, S. Financial logistics innovations in IT Project Management. MATEC Web Conf. $2018,193,5062$. [CrossRef]

3. Vial, G. Understanding digital transformation: A review and a research agenda. J. Strateg. Inf. Syst. 2019, 28, 118-144. [CrossRef]

4. Litvinenko, V.S.; Tsvetkov, P.S.; Molodtsov, K.V. The social and market mechanism of sustainable development of public companies in the mineral resource sector. Eurasian Min. 2020, 36-41. [CrossRef]

5. Vilken, V.; Kalinina, O.; Barykin, S.; Zotova, E. Logistic methodology of development of the regional digital economy. IOP Conf. Ser. Mater. Sci. Eng. 2019, 497, 12037. [CrossRef]

6. Bril, A.; Kalinina, O.; Levina, A. Two-stage commercial evaluation of engineering systems production projects for high-rise buildings. E3S Web Conf. 2018, 33, 3004. [CrossRef]

7. Bril, A.; Kalinina, O.; Valebnikova, O. Innovation Venture Financing Projects in Information Technology. In Internet of Things, Smart Spaces, and Next Generation Networks and Systems; Galinina, O., Balandin, S., Koucheryavy, Y., Eds.; Springer International Publishing: Cham, Switzerland, 2016; Volume 9870, pp. 766-775. ISBN 9783319463001.

8. Fernandes, N. Economic Effects of Coronavirus Outbreak (COVID-19) on the World Economy. SSRN Electron. J. 2020. [CrossRef]

9. Porter, M.E. Clusters and the New Economics of Competition. Harv. Bus. Rev. 1998, 76, 77-90. [PubMed]

10. Chen, H.; Qian, W.; Wen, Q. The Impact of the COVID-19 Pandemic on Consumption: Learning from High Frequency Transaction Data. SSRN Electron. J. 2020. [CrossRef]

11. Rajput, H.; Changotra, R.; Rajput, P.; Gautam, S.; Gollakota, A.R.K.; Arora, A.S. A shock like no other: Coronavirus rattles commodity markets. Environ. Dev. Sustain. 2020. [CrossRef] [PubMed]

12. Ivanov, D.; Dolgui, A. Viability of intertwined supply networks: Extending the supply chain resilience angles towards survivability. A position paper motivated by COVID-19 outbreak. Int. J. Prod. Res. 2020, 58, 2904-2915. [CrossRef]

13. Ebinger, F.; Omondi, B. Leveraging Digital Approaches for Transparency in Sustainable Supply Chains: A Conceptual Paper. Sustainability 2020, 12, 6129. [CrossRef]

14. Karia, N. Knowledge resources, technology resources and competitive advantage of logistics service providers. Knowl. Manag. Res. Pract. 2018, 16, 414-426. [CrossRef]

15. Lukinsky, V.S.; Serova, E.G. Methods and tools of data mining in digital logistics and supply chain management. Logist. Supply Chain Manag. 2018, 4, 73-80.

16. Sergeev, V.I. Prospects for the development of digital logistics and UTS in Russia and the role of the HSE school of logistics. Logist. Supply Chain Manag. 2017, 6, 3-14.

17. Kache, F.; Seuring, S. Challenges and opportunities of digital information at the intersection of Big Data Analytics and supply chain management. Int. J. Oper. Prod. Manag. 2017, 37, 10-36. [CrossRef]

18. Sergeev, V.I.; Dutikov, I.M. Digital supply chain management: A look into the future. Logist. Supply Chain Manag. $2017,2,87-97$.

19. Giménez, C.; Lourenço, H.R. e-SCM: Internet's impact on supply chain processes. Int. J. Logist. Manag. 2008, 19, 309-343. [CrossRef]

20. Barykin, S.; Kobicheva, A. Logistical approach to universities integration in the Russian innovation economy. MATEC Web Conf. 2018, 170, 1020. [CrossRef]

21. Antipin, F.A. Omnichannel trade in Russia in the realities of the modern economic situation. Russ. Entrep. 2017, 18, 733-748.

22. Buldeo Rai, H.; Verlinde, S.; Macharis, C.; Schoutteet, P.; Vanhaverbeke, L. Logistics outsourcing in omnichannel retail. Int. J. Phys. Distrib. Logist. Manag. 2019, 49, 267-286. [CrossRef]

23. Silkina, G.Y.; Shcherbakov, V.V. Modern Trends in Digitalization of Logistics; POLYTECH-PRESS: St. Petersburg, Russia, 2019.

24. Bowersox, D.J.; Closs, D.J. Logistical Management: The Integrated Supply Chain Process; McGraw-Hill Companies: New York, NY, USA, 1996; ISBN 9780070068834.

25. Dent, J. Distribution Channels: Understanding and Managing Channels to Market, 2nd ed.; Kogan Page: London, UK; Philadelphia, PA, USA, 2011; ISBN1 9780749462697. ISBN2 9780749452568.

26. Tkach, V.V.; Vorobyova, O.A. Transactional limitations of integrated supply planning. FES Financ. Econ. Strateg. 2017, 3, 40-46.

27. Eferin, Y.; Hohlov, Y.; Rossotto, C. Digital platforms in Russia: Competition between national and foreign multi-sided platforms stimulates growth and innovation. Digit. Policy Regul. Gov. 2019, 21, 129-145. [CrossRef]

28. Gorchels, L.; West, C.; Marien, E.J. The Managers Guide to Distribution Channels; McGraw-Hill: New York, NY, USA, 2004; ISBN 9780071428682.

29. Brookes, M. Marketing Channels, 6th ed.; Coughlan, A.T., Ed.; Prentice Hall: Upper Saddle River, NJ, USA, 2015; ISBN 9780130127723.

30. Michel, S.; Saucède, F.; Pardo, C.; Fenneteau, H. Business interaction and institutional work: When intermediaries make efforts to change their position. Ind. Mark. Manag. 2019, 80, 266-279. [CrossRef]

31. Parfenov, A.V.; Tkach, V.V. Logistic imperatives of forming an omnichannel model of wholesale trade. News Saint Petersbg. State Univ. Econ. 2020, 2, 116-121. 
32. Christensen, J.F.; Olesen, M.H.; Kjær, J.S. The industrial dynamics of Open Innovation—Evidence from the transformation of consumer electronics. Res. Policy 2005, 34, 1533-1549. [CrossRef]

33. Al-Hazmi, N.M. The impact of information technology on the design of distribution channels. Uncertain Supply Chain Manag. 2020, 505-512. [CrossRef]

34. Tarondeau, J.-C.; Xardel, D. La Distribution; Presses Universitaires de France: Paris, France, 1985; ISBN 9782130388364.

35. Dybskaya, I.V.; Sergeev, V.I. Digital transformation of supply chains of chain retail enterprises. Logist. Supply Chain Manag. 2019, 4, 3-16.

36. Geng, X.; Tan, Y.R.; Wei, L. How Add-on Pricing Interacts with Distribution Contracts. Prod. Oper. Manag. 2018, $27,605-623$. [CrossRef]

37. Tsao, Y.C.; Thanh, V.V.; Wu, Q. Sustainable microgrid design considering blockchain technology for real-time price-based demand response programs. Int. J. Electr. Power Energy Syst. 2021, 125, 106418. [CrossRef]

38. Camarinha-Matos, L.M.; Fornasiero, R.; Ramezani, J.; Ferrada, F. Collaborative Networks: A Pillar of Digital Transformation. Appl. Sci. 2019, 9, 5431. [CrossRef]

39. Zoller, S.S. Omnichannel retail trade-the basis for analysis and evaluation of the effectiveness of the logistics system. Logist. Supply Chain Manag. 2019, 92, 29-39.

40. Yun, J.J.; Kim, D.; Yan, M.R. Open innovation engineering-Preliminary study on new entrance of technology to market. Electronics 2020, 9, 791. [CrossRef] 